\title{
Biochemical evaluation of glycemic levels of long-term tacrolimus therapy in rats
}

\author{
Avaliação bioquímica dos níves glicêmicos da \\ terapia com tacrolimo por longo período em \\ ratos
}

\section{Carlos Augusto Nassar ${ }^{(a)}$ \\ Patricia Oehlmeyer Nassar ${ }^{(b)}$ \\ Denise Carleto Andia (c) \\ Morgana Rodrigues Guimarães(c) \\ Maria Teresa Pepato(d) \\ Luis Carlos Spolidorio(e)}

\author{
(a) Adjunct Professor; (b) Assistant Professor \\ - Department of Periodontology, School of \\ Dentistry of Cascavel, State University of the \\ West of Parana. \\ (c) Graduate students, Department of \\ Periodontology; (e)Adjunct Professor, \\ Department of Oral Pathology - School of \\ Dentistry of Araraquara, São Paulo State \\ University. \\ (d) Adjunct Professor, Department of \\ Biochemistry, School of Pharmaceutical \\ Sciences of Araraquara, São Paulo State \\ University.
}

\begin{abstract}
One of the more serious complications following transplantation is the development of post-transplantation diabetes mellitus (PTDM), which has a major impact on the quality of life, with effects ranging from the control of glycemia times to increased susceptibility to infections and cardiovascular complications. It has been suggested that immunosuppressive therapy, mainly tacrolimus therapy, may be an important factor in the development of PTDM. There is a lack of studies that explore the effects of long-term tacrolimus on PTDM in animal protocols. The objective of this study was therefore to evaluate the effects of long-term therapy with tacrolimus in rats. One group was treated with tacrolimus, injected subcutaneously, in a daily dose of $1 \mathrm{mg} / \mathrm{kg}$ of body weight. The chosen dose was sufficient to achieve therapeutic tacrolimus serum levels. The experimental periods were 60, 120, 180 and 240 days. One group was used as control and received daily subcutaneous injections of saline solution during all periods. A tendency towards increased glycemia levels during the initial periods (60 and 120 days) was observed. However, at 180 and 240 days, the glycemia levels were not statistically different from that of the control group of the same period. It may thus be concluded that the deleterious effects of tacrolimus therapy on glycemia may be a time-related side effect.
\end{abstract}

Descriptors: Tacrolimus/adverse effects; Glycemic index; Diabetes mellitus; Rats.

Resumo: Uma das mais sérias complicações pós-transplante é o desenvolvimento de Diabetes Mellitus Pós-Transplante (DMPT), que irá produzir um grande impacto na qualidade de vida, com variações do controle glicêmico, aumentando a susceptibilidade a infecções e complicações cardiovasculares. Tem sido sugerido que a terapia imunossupressora, principalmente com tacrolimo, pode ser um importante fator no desenvolvimento de DMPT. Existem atualmente poucos estudos explorando os efeitos de um longo período de terapia com tacrolimo sobre DMPT em protocolos animais. Portanto, o objetivo deste estudo foi avaliar o efeito glicêmico de uma terapia por longo período com tacrolimo em ratos. Um grupo foi tratado com tacrolimo com doses diárias subcutâneas de $1 \mathrm{mg} / \mathrm{kg}$ de peso corporal. A escolha dessa dose foi suficiente para a obtenção dos níveis séricos terapêuticos desejados com tacrolimo. Os períodos experimentais foram 60, 120, $180 \mathrm{e}$ 240 dias. Outro grupo foi usado como controle e recebeu injeções salinas subcutâneas diariamente durante todos os períodos. Houve uma tendência ao aumento do nível glicêmico nos períodos iniciais (60 e 120 dias). Entretanto, após 180 e 240 dias, os níveis de glicemia não foram estatisticamente diferentes dos obtidos nos grupos controles de mesmo período. Assim, pode-se concluir que os efeitos glicêmicos adversos provocados pela terapia com tacrolimo podem ser relacionados ao tempo.

Descritores: Tacrolimo/efeitos adversos; Índice glicêmico; Diabetes mellitus; Ratos. 


\section{Introduction}

Immunosuppressant drugs (tacrolimus, mycophenolate mofetil (MMF) and sirolimus) have dramatically improved graft and transplant survival. ${ }^{7,11}$ One of the most serious complications after transplantation is the development of post-transplantation diabetes mellitus (PTDM), which has a major impact on quality of life, with effects ranging from the control of glycemia times to increased susceptibility to infections and cardiovascular complications. ${ }^{2}$ The influence of diabetes on periodontal tissue is being constantly investigated. Although it is difficult to provide definitive conclusions on the specific effect of diabetes on the periodontium, a variety of alterations have been described, including a trend towards generalized gingival overgrowth, dental abscesses, periodontitis and dental loss. The major consequence of uncontrolled diabetes is possibly the reduction of the defense mechanisms and increased susceptibility to infections, leading to destructive periodontal disease ${ }^{1}$ or other oral complications. With the introduction of calcineurin inhibitors and the current use of lower doses of steroids, the incidence of PTDM has decreased (3-14\% of patients). However, PTDM remains an important complication after organ transplantation, ${ }^{2}$ where it seems to be associated with immunosuppressant therapy. ${ }^{7}$ It has been suggested that immunosuppressive therapy, mainly with FK-506, may be an important factor in the development of PTDM. In clinical studies, the effect of tacrolimus on PTDM has been studied extensively and revealed results demonstrating that tacrolimus patients suffer less acute rejection and less steroid-resistant rejection, but more insulin-requiring diabetes mellitus. ${ }^{11}$ The independent effects of tacrolimus on PTDM have been characterized in clinical studies, since transplant patients received combined therapy with tacrolimus together with corticosteroids. ${ }^{2}$ Conversely, the time of treatment is important; a US Renal Data System (USRDS) evaluation of the incidence, risk factors and outcomes in patients who developed PTDM estimated the cumulative incidence of PTDM to be $9.1 \%, 16.0 \%$ and $24.0 \%$ respectively at 3,12 and 36 months posttransplantation. ${ }^{6}$ In relation to early PTDM, there is limited information associating the prevalence of PTDM with the time of tacrolimus therapy. ${ }^{7}$ On the other hand, prospective studies after solid organ transplantation with glucose metabolism disorders as the primary endpoint have not been performed until now, although all comparisons between calcineurin inhibitors concerning PTDM showed a three to five times higher incidence with tacrolimus. Many questions remain unanswered due to the different criteria used for the diagnosis of diabetes mellitus (based on insulin requirement) or due to the high trough levels of tacrolimus targeted in initial studies; furthermore, data on the mechanism of glucose metabolism disturbance with tacrolimus are contradictory. ${ }^{7}$ Therefore, the objective of this study was to evaluate the effects of long-term therapy with tacrolimus in rat.

\section{Material and Methods}

Eighty male Holtzman rats (Rattus norvegicus Albinus) weighing $50 \mathrm{~g}$ were housed under similar conditions in cages with access to food and water ad libitum. The animals were randomly distributed into two groups of 40 animals each. All protocols described below were approved by the Institutional Experimentation Committee, School of Dentistry of Araraquara, Araraquara, SP, Brazil. One group was treated with tacrolimus (Prograf ${ }^{\circledR}$ - Janssen Cilag, São José dos Campos, SP, Brazil) injected subcutaneously in a daily dose of $1 \mathrm{mg} / \mathrm{kg}$ of body weight., One group was used as a control group and received subcutaneous injections of saline solution during the entire period. The experimental periods were 60, 120, 180 and 240 days. The rats were weighed weekly and monitored for the appearance of abnormal coat, abnormal level of physical activity. At the end of the experimental periods, the rats were anesthetized with $0.08 \mathrm{mg}$ of Ketamine/100 g of body weight (Francotar ${ }^{\circledR}$, Virbac do Brazil Ind. e Com. Ltda., São Paulo, SP, Brazil) and 4-5 $\mathrm{ml}$ of blood were obtained by direct cardiac puncture in heparinized capillary tubes for immediate glycemia measurements, using colorimetric kits (Glucose - PAP Kit, Labtest Ind. e Com. Ltda., Ribeirão Preto, SP, Brazil). Levels of FK-506 were determined at the end of each experimental period. After blood collection, the rats were killed by an overdose of anesthesia. 
Variance analysis (ANOVA) was used for statistical evaluation. Tukey's test was used to compare differences between groups. $\mathrm{P}<0.01$ was considered significant.

\section{Results}

Graph 1 shows the glycemic levels for the control and tacrolimus-treated rats. In the control group, the glycemia levels ranged between $110.0 \pm 1.1 \mathrm{mg} /$ $\mathrm{dL}$ and $130.0 \pm 2.0 \mathrm{mg} / \mathrm{dL}$. The tacrolimus treated

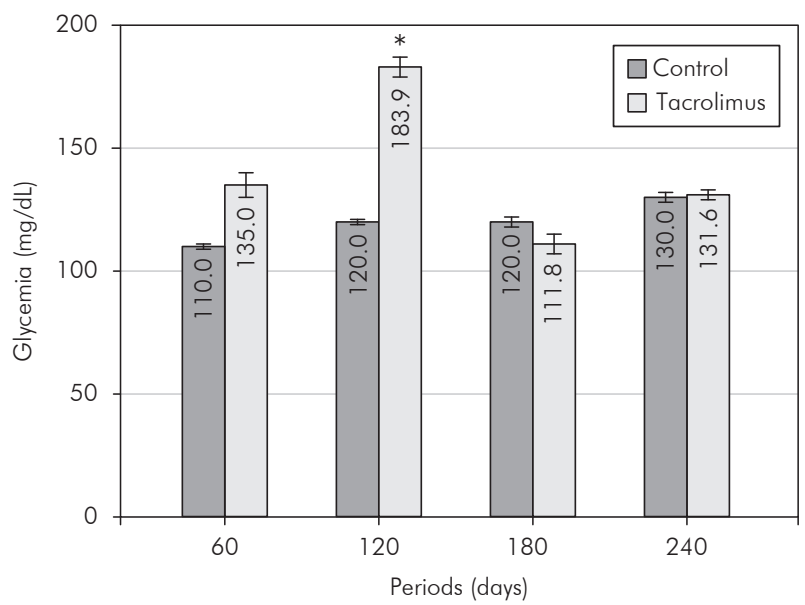

Graph 1 - Measurements (means \pm standard deviations) of the serum glycemia levels in control rats and in tacrolimustreated rats during the treatment periods. $\left({ }^{*} p<0.01\right.$, statistical significance, control group vs. tacrolimus groups in the different periods.)

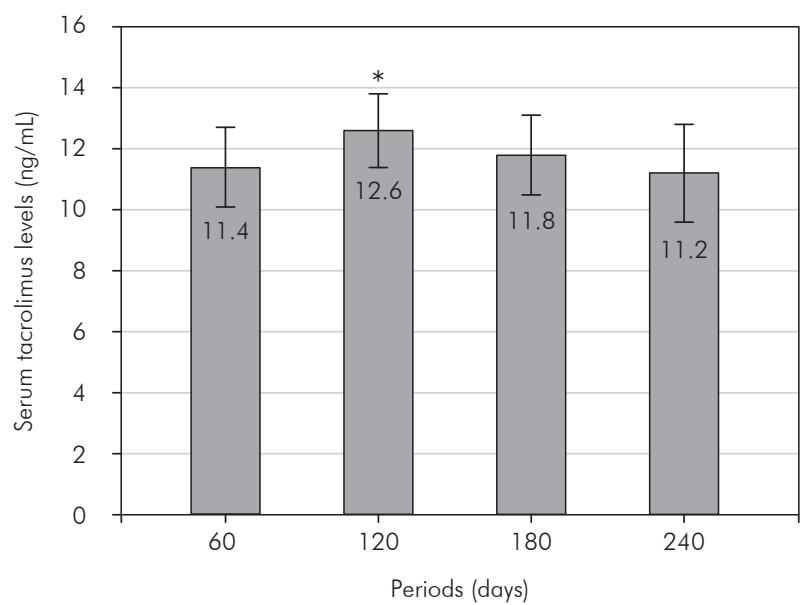

Graph 2 - Measurements (means \pm standard deviations) of the serum tacrolimus levels in tacrolimus-treated rats during the treatment periods. ( ${ }^{*} p<0.01$, statistical significance, tacrolimus groups in the different periods.) groups showed a discreet increase in the initial period (60 days). However, these values were not statistically different from those of the control group $(p>0.05)$. The glycemia levels of the tacrolimustreated rats were significantly increased after 120 days of treatment, compared with those of the control group. After 180 and 240 days, the glycemia levels in the tacrolimus-treated rats decreased significantly and were not statistically different from those of the control group.

At the end of the experimental periods, the serum levels of tacrolimus were $11.4 \pm 1.3 \mathrm{ng} / \mathrm{mL}$ (60 days); $12.6 \pm 1.2 \mathrm{ng} / \mathrm{mL}$ (120 days); $11.8 \pm 1.3 \mathrm{ng} / \mathrm{mL}(180$ days); and $11.2 \pm 1.6 \mathrm{ng} / \mathrm{mL}$ (240 days). The serum levels of tacrolimus were significantly increased after 120 days of treatment compared with those of the other experimental periods $(\mathrm{p}<0.01)$ (see Graph 2$)$.

Graph 3 shows the body weight of the rats treated, or not, with tacrolimus. After 60 days, the body weights of the control group and of the experimental group were $283.6 \pm 1.0 \mathrm{~g}$ and $282.2 \pm 2.0 \mathrm{~g}$, respectively ( $\mathrm{p}>0.05$ ). After 120 days, no significant differences were observed between body weights, which were $418.0 \pm 3.0 \mathrm{~g}$ for the control group and $416.9 \pm 3.0 \mathrm{~g}$ for the experimental group $(\mathrm{p}>0.05)$. After 180 days, the body weight in the control group was $478.0 \pm 2.0 \mathrm{~g}$, while the body weight in the group treated with tacrolimus decreased

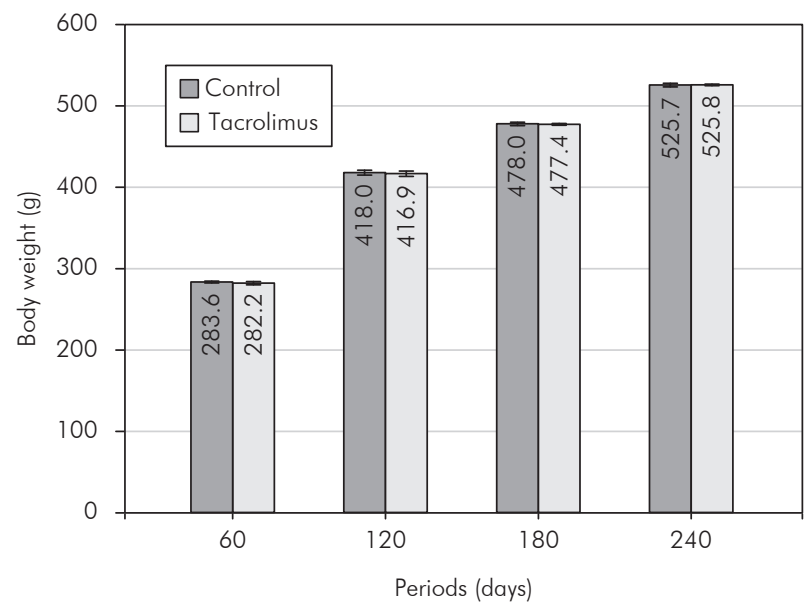

Graph 3 - Measurements (means \pm standard deviations) of body weight in the control and tacrolimus groups during the treatment period. ( $p>0.05$, no statistical significance, control group vs. tacrolimus group, in the different periods.) 
$(477.4 \pm 1.0 \mathrm{~g})$, but those values were not statistically different $(\mathrm{p}>0.05)$. After 240 days, the body weight in the control group was $525.7 \pm 2.0 \mathrm{~g}$, while the body weight in the group treated with tacrolimus was $525.8 \pm 1.0 \mathrm{~g}$, but those values were not statistically different $(\mathrm{p}>0.05)$.

\section{Discussion}

The present study evaluated glycemic levels following long-term administration of tacrolimus in an animal model. The relevance of this study centers on the longer period of observation of the effects of tacrolimus on glycemia levels, compared with other studies that have employed briefer periods of time. The results of the present investigation showed that tacrolimus administration during an initial period (60 days and 120 days) (Graph 1), in a dose that has been reported to be immunosuppressive $(1 \mathrm{mg} / \mathrm{kg}$ of body weight), ${ }^{4-5}$ induced an evident diabetogenic effect, where the treatment resulted in estimated peak and trough mean levels of tacrolimus of $11.7 \pm 1.3 \mathrm{ng} / \mathrm{mL}$ (Graph 2). This dose is clinically relevant and within the range of doses used in studies on organ and limb transplantation that usually are between 0.6 and $1.0 \mathrm{mg} / \mathrm{kg}$ of body weight, ${ }^{10}$ resulting in a consistent response. Although the exact mechanisms involved in the development of the tacrolimus-induced diabetes are not known, there is evidence that this drug inhibits insulin synthesis via an mRNA transcriptional defect or induces hyperinsulinemia, promoting insulin resistance. ${ }^{7-9}$ In agreement with other authors, tacrolimus is better than cyclosporin at improving graft survival and preventing acute rejection after kidney

\section{References}

1. Caldeira TC, Nassar CA, Massucato SEM, Orrico SRP, Nassar PO. Diabetes mellitus and periodontal disease: A bidirectional relation. Diabetes Clinica. 2005;9(3):212-7.

2. Drachenberg CB, Klassen DK, Weir MR, Wiland A, Fink JC, Bartlett ST et al. Islet cell damage associated with tacrolimus and cyclosporine: Morphological features in pancreas allograft biopsies and clinical correlation. Transplantation. 1999;68(3):396-402.

3. Ishida H, Mitamura T, Takahashi Y, Hisatomi A, Fukuhara Y, Murato K et al. Cataract development induced by repeated transplantation, but increases post-transplantation diabetes and neurological and gastrointestinal sideeffects. ${ }^{11}$ Interestingly, in the present study, a gradual time-related improvement was observed during longer periods of treatment (180 and 240 days). In these periods, the glycemia level values were similar to those of the control rats, ${ }^{8}$ although insulin and peptide $\mathrm{C}$ levels were not analyzed in this study. On the other hand, in agreement with other authors, diabetic parameters did not change in the 0.2 or $1 \mathrm{mg} / \mathrm{kg}$ of body weight/ day groups during some periods, and this observation suggests that diabetes develops in the rats dosed with $5 \mathrm{mg} / \mathrm{kg}$ of body weight/day of FK $506 .^{3}$ These results are in agreement with some prospective longitudinal studies in humans that show a relevant role of time in the reduction of the glycemia level. ${ }^{7}$ The results of the present study show that, in the group treated with tacrolimus, there was a decrease in body weight in comparison with the control group, although not statistically significant (Graph 3). The authors of the above-mentioned longitudinal studies suggested that the abnormalities in glucose metabolism may be normalized after prolonged therapy with tacrolimus.

\section{Conclusion}

Within the limits of this experimental study, it may be concluded that the negative effect of tacrolimus therapy on glycemia may be reversed with time. However, detailed studies are still needed to clarify the possible cellular and molecular mechanisms involved in the diminished effect of immunosuppressive drugs on the glycemia level after long-term administration. oral dosing with FK506 (tacrolimus) in adult rats. Toxicology. 1997;123(3):167-75.

4. Jiang H, Fujitsu T, Sakuma S, Ogawa T, Tamura K, Fujii Y et al. Immunosuppressive effects of FK 506 on rat renal allograft survival, in comparison with cyclosporine. Transplant Proc. 1995;27(1):367-9.

5. Jiang H, Takahara S, Takano Y, Li D, Kyo M, Valdivia LA et al. Effect of FK 506 on heart allograft survival in highly sensitized recipient rat in comparison with cyclosporine. Transplant Proc. 1991;23(1Pt1):540-1. 
6. Kasiske B, Snyder JJ, Gilbertson D, Matas A. Diabetes mellitus after kidney transplantation in the United States. Am J Transplant. 2003;3(2):178-85.

7. Maes BD, Kuypers D, Messiaen T, Evenepoel P, Mathieu C, Coosemans $\mathrm{W}$ et al. Posttransplantation diabetes mellitus in FK-506 treated renal transplant recipients: Analysis of incidence and risk factors. Transplantation. 2001;72(10):165561.

8. Mitruka BM, Rawnsley HM. Clinical Biochemical and Hematological Reference Values in Normal Experimental Animals and Normal Humans. $2^{\text {nd }}$ ed, Section VI, p. 160. New York: Masson; 1977.
9. Van Hooff JP, Van Duijnhoven EM, Christiaans MHL. Tacrolimus and glucose metabolism. Transplant Proc. 1999;31(7A):49S-50S.

10. Voggenreiter G, Siozos P, Hunkemoller E, Heute S, Schwarz M, Obertacke U. Immunosuppression with FK506 has no influence on fracture healing in the rat. Bone. 2005;37(2):22733.

11. Webster A, Woodroffe RC, Taylor RS, Chapman JR, Craig JC. Tacrolimus versus cyclosporin as primary immunosuppression for kidney transplant recipients. Cochrane Database Syst Rev. 2005;19(4):CD003961. DOI: 10.1002/14651858. CD003961. 